\title{
The Use of Non Linguistics Means Strategies as a Speaking-problem Solving in EFL Learning
}

\author{
Syamsudin \\ Department of English Language and Letters, Faculty of Humanities \\ State Islamic University ‘Maulana Malik Ibrahim’ of Malang East Java Indonesia \\ E-mail: syamsudinuin@yahoo.com
}

Received: April 28, 2016 Accepted: May 25, 2016 Published: May 29, 2016

doi:10.5296/ijele.v4i2.9531 URL: http://dx.doi.org/10.5296/ijele.v4i2.9531

\begin{abstract}
This study is about the use of non-linguistic means strategies as a part of communication strategies by the English Department students of one of the Islamic Universities of Malang as a means to solve their speaking problems. This paper aims at discussing the result of some observations and interviews to two students in the use of non-linguistic means strategies in EFL learning to handle their speaking problem. I am interested in discussing this topic because the use of non linguistic means strategies has helped EFL learners handle their speaking problems in EFL learning due to their limited knowledge on linguistic elements. It is necessary for the EFL learners to know more about non-linguistic means strategies as a part of communication strategies so that they might develop their speaking skill.
\end{abstract}

Keywords: use of non linguistic means, communication strategies, speaking-problem solving, linguistic elements 


\section{Introduction}

One of the most important skills that learners should learn in EFL learning is speaking. Speaking is very important because by mastering speaking learners might express their ideas to the interlocutors well so that they might achieve their communication goals. However to master speaking is not an easy thing. There are many students who have learned English for some years are still difficult to speak English fluently. According to Brown (1994) learners might get difficulty in speaking when learners have to focus on forms and function of the language. In addition, speaking has two sequential phases: planning and execution. Planning is done when speakers think of what utterance to be used to influence the listeners and execution is the realization of planning into words, phrases and sentences. Thus, Phases in language learningprocess especially in learning speaking might make learners get difficulties to master speaking. Besides, learners' difficulties to master speaking skill might be caused by learners' lack of understanding linguistic elements such as grammar, vocabularies and pronunciation.

To solve the difficulties to master speaking skill, EFL learners need to understand well about Communication Strategies (Ellis, 1994). Communication strategies are strategies that learners might use to solve their speaking problems. Using communication strategies learners might handle their speaking problems (Dornyei, 1995). Related to communication strategies, this study is going to discuss the use of non-linguistic means strategies as devices to solve learners' speaking problem. This study is more specifically going to discuss the reason why those learners used non linguistic means strategies to solve their speaking problems. It covers the description of research methods, discussion of findings related to theories of communicative competence, learners' proficiency and some other research findings related to communication strategies and conclusion.

\section{Description of Research Methods}

In conducting this research, I used a qualitative case study design. A case study is a detailed examination of one setting, or a single subject, a single depository of documents, or one particular event (Merriam, 1988). In a qualitative research in education, the researcher depends on the research participants. The researcher collects the data from the subjects in the form of words and he describes and analyzes these words based on themes (Creswell, 2002:46). The strength of qualitative data is their richness and wholeness, with strong potential for revealing complexity; such data provide "thick description" that are vivid, nested to the real context and truthful (Miles and Huberman, 1994). In this research, I used two EFL learners as the subjects. Subjectl is identified as Min and subject 2 is identified as Din. These two EFL learners were chosen based on their criteria of being very active in every meeting of the speaking class. In this study, I focused on finding the use of non-linguistic means strategies used by the two learners and the reason why they apply those strategies in the conversation. 
The data in this research were in the form of learners' verbal and non-verbal expressions or behaviors. Learners' verbal expressions were got from the utterances expressed by the learners when they had conversation and discussions with their speaking partners. These learners' verbal expressions were recorded and then transcribed to produce transcribed data or texts. And learners' non-verbal behaviors were in the form of hands movements, eyes contacts, mimes and smiles. These learners' non-verbal behaviors were got when they were having conversations or discussions with their speaking partners. According to Bogdan and Biklen (1992) the data are the particular information that shapes the basis of analysis. Data would include all things that people are doing in the study. Data would also consist of what others have created and the researchers find such as diaries, photographs, official documents, and newspaper articles. In addition, data refer to all information needed and are collected by the researcher as the basis to answer the research questions (Susanto, 2010). Thus the data are very important in the research and they are needed to answer the research questions.

In this research, the data were collected through observation and in-depth interview. In the observation, I acted as the non participatory observer and I observed the subjects when they had conversations and the discussions with their friends. During the observation, I recorded learners' utterances using a mini recorder and noted some expressions or behaviors that they did throughout the conversation or the discussion. Next, I interviewed them in what context and why they used non linguistic means strategies in the conversation. Subsequently, I transcribed the recorded data and discussed the transcribed data related to some theories of learners' proficiency, communicative competence, communication strategies and some other research findings on communication strategies.

\section{Discussion on Findings}

From the analysis, it is found that the subject 1, Min often used use of non-linguistic means strategies in the conversation. It was known when he was having a conversation with his lecturer in the English department office. The situation in the office was quiet enough so that they both enjoyed their conversation. In the conversation, Min was found to use some expressions like hands movements, eyes contacts and smiles. For example, when he told that he had speaking class at 06.30 he expressed it by using his hands to show the word 'six'. He said: “...ee actually I have class at six and thirty...”.It also happened when he said that his lecturer could not come at that time due to go to Jakarta. He said that his lecturer would come to the class next week. He said: “... she went to Jakarta and she will go back to here ee next week". He expressed the words six and next week by using his hands. Next, he was found to employ eyes contacts during the conversation. Then, he smiled several times to his speaking partner while nodding. In this case, he used some expressions like the use of hands movements, eye contacts and smiles to convince his speaking partner. The use of non linguistic means strategy was very important for him because it could help him express what he wanted to say. Besides, he stated that it create a communicative speaking. Further, he stated that non linguistic means strategies have helped his speaking partner understand him easily. 
An important point to be noted here is that Min used non linguistic means strategies using some expressions like hands movements, eyes contacts, and smiles during the conversation. It was done because he found that by using the use non linguistic means strategies he felt relaxed so that he could express his ideas fluently. He further stated that the use of non linguistic means strategies might help the interlocutor understand him easily.

Subject 2, Din employed non linguistic means strategy. It was known when Din was discussing with his two other friends about favorite food. The discussion took place in thecafeteria. In the conversation, Din was found to use some expressions like hands movements, mimes, eyes contacts, and smiles. He often used hands movements during the conversation. For example, he employed it when he wanted to describe how to make soto. He said:"...Soto ayam is ee the food that is made from chicken and rice and some soup and I like to eat that because it is really eeee fresh to be my ee my lunch...". In telling about how to make soto, he used his fingers to tell chronologically to count for the rice, chicken and soup. At the same time, he was also doing some smiles, eyes contacts and mimes during the conversation. He stared his speaking partner frequently in the conversation. Next, He smiled several times. Hands movements, mimes, eyes contacts, and smileswere very important for him because by using these strategies he could decrease feeling nervous and feel more comfortable during the conversation. This feeling further brought him to speak more fluently. He said: “ ... to lose my nervousness I I use my hands ... I feel comfortable to speak when my hands move...".

An important point to be noted is that Din used non linguistic means strategies using some expressions like hands movements, eyes contacts, and also smiles during the conversation. By using the use of non linguistic means strategies he might decrease his feeling nervous and felt more comfortable in the conversation. The use of non linguistic means strategies might further help him speak more fluently and also might help him induce his speaking partner.

From the findings above, an important point to be noted is that both EFL learners have used non linguistic means strategies such as hands movements, mimes, eyes contacts, and smiles in the conversation. The use of non linguistic means strategies might help learners handle some speaking problems. In general, learners' speaking problems were caused by their limited mastery of linguistic elements such as being lack of vocabularies or grammar mastery. According to Bialystok (1990) shortage of linguistic elements might bring gaps of knowledge of second language. In speaking these gaps might influence fluency. In addition, Ellis (1994) states those learners' problems in speaking arecommonly caused by their lack of mastering some elements in L2. In general, the shortage of the second language might be in the form of a word, a structure, a phrase, a tense marker or an idiom. Then, learners' limitedness on second language might cause difficulties in speaking (Stern, 1983). Finally, learners' limited or imperfect knowledge of rules in EFL might bring communication problems (Karimnia and Zade, 2007).

To handle their speaking problems both learners used non linguistic means strategies. Using non linguistic means strategies as parts of communication strategies, they might solve their speaking problems. This is relevant to Dornyei (1995) who states that communication 
strategies are the strategies that learners employ to handle their communication problems. Next, using communication strategies learners could handle their linguistic problems and talk more comprehensibly (Bialystok, 1990). Thus, by employing communication strategies learners might handle their communication problems due to their linguistic problems. For example, when learners try to communicate and the needed linguistic items are not available, they might employ communication strategies to achieve their communication goals. Using communication strategies, a central component in interlanguage, learners might handle their limitedness in interlanguage resources (Ellis, 1994). Dealing with the importance of mastering linguistic elements to develop speaking, Nunan (1991) states that to be able to speak well, learners should master some language elements such as grammar, vocabulary, intonation, pronunciation, stress, and the choice of language functions.

The study found that both learners used non linguistic means strategies consciously in speaking. They realized that the use of non linguistic means strategies as parts of communication strategies might help them solve their communication problems. It was shown by their use these strategies again and again during communication. In relation to the use of communication strategies consciously in communication, Faerch\& Kasper (1983) state that communication strategies are learners' conscious plans for solving problems in reaching communicative goals. In addition, Brown (1987: 180) states that communication strategies are a conscious employment of verbal and nonverbal mechanism to communicate ideas when precise linguistic forms are not available to the learners during the communication.

Next, the study found that both learners liked use communication strategies to handle their communication problems during communication. It was found that their interlocutors could understand them when they employed certain communication strategies to reach their communication goals. This mutual understanding had made them have more fluent conversation to reach their communication goals. Dealing with the function of communication which might create learners' mutual understanding/meaning during communication, Tarone (1980) states that communication strategies might make learners create mutual understanding with their interlocutors. Next, this might bring to attain the required meaning when requisite meaning structures are not shared. Thus, learners who stress the importance of using the language often use communication strategies (Wenden and Rubin, 1987).

The study indicated that learners' usage of communication strategies in speaking was influenced by learners' language proficiency. This study agrees with Mei and Nathalang's (2007) and Huang's (2010) finding stating that the usage of communication strategies was influenced by language proficiency. The data indicated that both learners used some communication strategies. And one of the communication strategies that they used frequently was the use of non linguistic means. Using non linguistic means strategies they might solve their speaking problem due to their limited vocabularies. In addition, they became more relaxed, comfortable, convincing, and communicative so that the conversation might work well and the interlocutor might comprehend them well. Next, the study found that being classified as the proficient learners both learners employ communication strategies efficiently. For example, they were found to use more non verbal communication strategies such as 
hands movements, eyes contacts, smiles, and mimes during communication. In this case, the use of communication strategies reflects learners' language development. The finding of the study above is in accordance with Ellis (2008) who concludes that the strategies that learners choose to use reflect their general stage of L2 development, proficient learners tend to use learning strategies more frequently and qualitatively in different ways than learners who are less proficient and different kinds of learning strategies may contribute to different aspects of L2 proficiency. Afterward, in relation to the language ability and proficiency, Skehan (1986a, 1986b, 1990) reported significant correlations between aptitude and measures of all for language skills including speaking. In addition, there was strong correlations strong correlation between language aptitude and L2 proficiency (Harley and Hart, 1997). In brief, language aptitude predicts successful learning in learners with formal as well as informal learning experience and correlates with measures of communicative as well as controlled language use (Ellis, 2008).

The study found that using communication strategies especially the use of non linguistic means strategies brought both learners to speak more enthusiastically and fluently. It was shown in the conversation and the discussion that happened with them in the classroom and outside the classroom. They employed non linguistic means strategies frequently. The study indicated that using use of non linguistic means strategies both learners were very motivated to improve their speaking. Thus, the use of communication strategies has motivated learners to practice speaking more and more. In relation to the use of communication strategies and motivation, this study agrees to Gardner (1985) in Ellis (2008) who state that motivation could gives a causative variables and modification of learners' attitudes could arise of a result of positive learning experiences. Further, Spolsky (1989) in Ellis (2008) states that greater motivation and attitudes lead to better learning. Thus, the use of communication strategies might crop up learners' motivation to practice speaking more and by doing more speaking practices learners might improve their speaking skill.

\section{Conclusions}

In brief, the use non-linguistic means strategies as parts of communication strategies are very important for EFL learners to develop their speaking skill.Using non-linguistic means strategies in the conversation makes learners feel relaxed and comfortable so that they might handle their speaking problems to reach their speaking goals. The use of non linguistic means strategies has increased learners' motivation and enthusiasm to practice speaking more so that they might improve their speaking skill. Thus, it is necessary to arise learners' alertness on the importance of the use of non linguistic means strategies in speaking class in EFL learning to improve learners' speaking skill. Above all, learners need to improve their understanding about linguistic elements such as grammar and vocabularies so that they might speak better and fluently. 


\section{References}

Bogdan, R. C., \& Biklen, S. K. (1992). Qualitative Research for Education: An Introduction to Theory and Methods. Boston: Allyn and Bacon.

Bialystok, E. (1990). Communication Strategies: A Psychological Analysis of Second-Language Use. London: Basil Blackwell.

Brown, Douglas H. (1987). Principles of Language Learning and Teaching. New Jersey: Prentice Hall.

Brown, Douglas H. (1994). Teaching by Principles.An Interactive approach to Language Pedagogy. New Jersey: Prentice Hall

Creswell, J. W. (2007). Qualitative Inquiry and Research Design. London: SAGE Publications.

Dornyei, Z. (1995). On the Teachability of Communication Strategies. TESOL Quarterly, (29), 55-58. http://www.zoltandornyei.co.uk/uploads/1995-dornyei-tq.pdf

Ellis, Rod. (1994). The Study of Second Language acquisition. Oxford: Oxford University Press.

Ellis, Rod. (2008). The Study of Second Language acquisition (2 nd.). Oxford: Oxford University Press.

Faerch, C., \& Kasper, G. (1983). Startegies in Interlanguage Communication. London: Longman.

Haastrup, K., \& Phillipson. R. (1983). Achievement Strategies in Learner/Native Speaker Interaction. In C. Faerch, \& G. Kasper (Eds.), Strategies in Interlanguage Communication. London: Longman.

Huang, C. P. (2010). Exploring factors Affecting the Use of Oral Communication Strategies. ELT Journal, 85-13. http://www.lhu.edu.tw/m/oaa/synthetic/publish/publish/30/8. 黃秋萍 -Exploring\%20Factors\%20Affecting\%20the\%20Use \%20of\%20Oral\%20Communication\%20 Strategies.pdf

Karimnia, A., \& Zade, S. S. (2007). Communication Strategies: English Language Departments in Iran. Iranian Journal of Language Studies (IJLS), (1), 287-300. http://www.ijls.net/vol1no4.html

Mei, A., \& Nathalang S. S. (2010). Use of Communication Strategies by Chinese EFL Learners. Chinese Journal of Applied Linguistics, 33(3), 110-125. http://www.celea.org.cn/teic/91/10091708.pdf

Merriam, S. B. (1998). The Case Study Research in Education. San Francisco: Jossey-Bass.

Miles, M. B., \& Huberman, A. M. (1984). Qualitative Data Analysis. California: SAGE Publication, Inc. 


\section{Macrothink}

International Journal of English Language Education

ISSN 2325-0887

2016, Vol. 4, No. 2

Nunan, D. (1991). Language Teaching Methodology. A Textbook for Teachers. New York: Prentice Hall International, Ltd.

Stern, H. (1983). Fundamental Concepts of Language Teaching. Oxford: Oxford University Press.

Susanto. (2010). Konsep Penelitian Tindakan Kelas dan Penerapannya. Surabaya: Lembaga Penerbitan FBS UNESA.

Tarone, E. (1980). Communication Strategies, foreigner talk and repair in interlanguage. Language Learning, (30), 417-431. http://dx.doi.org/10.1111/j.1467-1770.1980.tb00326.x

Wenden, A., \& Rubin, J. (1987). Learner Strategies in Language Learning. Hemel Hempstead: Prentice Hall International.

\section{Copyright Disclaimer}

Copyright for this article is retained by the author(s), with first publication rights granted to the journal.

This is an open-access article distributed under the terms and conditions of the Creative Commons Attribution license (http://creativecommons.org/licenses/by/3.0/). 